\title{
Estimating the Performance Ratio and Degradation Factor of Rooftop Solar PV Plant
}

\author{
Rajesh Kumar Prakhya ${ }^{1}$ and Ch.Lokeshwar Reddy ${ }^{2}$ \\ ${ }^{1}$ Assoc. Professor, CVR College of Engineering /EEE Department, Hyderabad, India \\ Email: rajeeecvr@gmail.com \\ ${ }^{2}$ Assoc. Professor, CVR College of Engineering /EEE Department, Hyderabad, India \\ Email: reddy.lokeshwar@gmail.com
}

\begin{abstract}
This paper investigates the effect of degradation on the grid connected rooftop solar plant. The effect of degradation and plant performance are evaluated and analyzed for $20 \mathrm{kWp}$ SPV plant on rooftop of EEE Block in CVR College of Engineering for the year 2015 and 2016. The above analysis is done manually from the plant data extracted from web-interface. The degradation of the plant is analyzed by first calculating the performance ratio of the plant for two successive years. Later the percentage change in the plant Performance Ratio's are calculated. This investigation reveals that degradation of the plant performance is high in summer season because of increased ambient temperature. The degradation is more during the month of May and less during the month of February. The reasons for this kind of performance are analyzed. After analyzing the results, it is recommended that plant should be maintained and inspected at regular interval for the improved performance.
\end{abstract}

Keywords: Degradation factor, Grid Connected Solar PV Plant, Panel degradation, Performance Metrics, Performance Ratio (PR), System Performance.

\section{INTRODUCTION}

One of the best ways to generate electrical energy from the solar radiation is by Photo-Voltaic effect. In this process the solar radiation is directly converted into DC electrical energy using the Solar Cell. One solar cell can generate only small amount of electrical power. Hence, to generate moderate power, large number of solar cells are connected either in series or parallel to form a Solar array to get the required electrical power from solar energy.

Grid connected PV systems are widely being used because of their own advantages. Power production from these Solar PV plants to be monitored properly for better utilization of plant and available resources [1-4]. The performance of these plants cannot be judged easily by considering the quantity of energy generated from the plant every day. The output of solar plant depends upon the amount of solar irradiation that falls on effective surface area of Solar PV array. This solar radiation is not the same throughout the year and every location. It is good in summer, adequate in winter and moderate in monsoon season. Hence, justifying the performance of the plant based on the amount of electrical energy generated by the plant is not hypothetical. Therefore, to analyze the performance of PV plants, few metrics are essential. Performance Ratio $(\mathrm{PR})$ is the most important metric that is adopted by the solar industry experts to analyze the performance of the plant.

Climatic conditions like high temperature and high humidity have negative influence on performance and consistency of the SPV modules. Besides the module performance, inverter efficiency is also a significant factor which greatly impacts the overall performance of the system and behavior. Besides temperature, many factors that influence the performance of SPV plants are solar insolation, shading effect, effect of climate, wind speed, electrical load matching, dust on panels, accuracy of MPPT operation and various losses that are occurring in the system like array capture losses, soil losses, inverter losses, etc. The solar industry experts need to understand every influencing parameter and its effect on the performance of plant. [5-6].

Performance of the PV module decreases at faster rate compared to other equipment, as modules are exposed to direct weather conditions. The degradation rate is normally high in the first year upon initial exposure to the solar light. Later it stabilizes. Factors affecting the degree of degradation include, quality of the material used in manufacturing, packing of solar cells, process of manufacturing modules and solar cell technology.

Factors for degradation are high winds, soil, dust, snow, fog, discoloration, lamination defects, mechanical stress and cell contact breakdown. Another important factor is breakage of Ethylene Vinyl Acetate (EVA) encapsulation, which is used as a back sheet of the PV module by UV light.

One of the important factors to be considered is that, all the modules will not degrade at same rate. Their degradation rate is different from one module to another module. Proper maintenance and inspection should be done at the site in regular intervals for better performance of the plant over a long time.

In this paper, Section II describes the location of the plant and capacities of the sub-plants located in the site. Section III, clearly discusses the performance analysis of Grid connected plant using Performance Ratio and Degradation Factor in detail. Section IV, systematically analyzes the results and discussion on Plant performance using these parameters followed by conclusion and references. 


\section{SPECIFICATIONS OF GRID CONNECTED SPV Plant}

Specifications and design of every grid connected SPV plant depends upon many factors like weather conditions, local load requirements, nature of the loads, maximum demand etc. The geographical coordinates of site/plant determine the seasonal tilt angle of the solar modules.

\section{A. Location of the plant}

The grid connected SPV plant for this investigation is located on the rooftop of the CVR College of Engineering, Hyderabad, Telangana state. The global coordinates of the site are Latitude: $17.20^{\circ} \mathrm{N}$, Longitude: $78.60^{\circ} \mathrm{E}$. This site location is at an altitude of $545 \mathrm{~m}$. above the sea level.

\section{B. Capacities Of Photo Voltaic Plant}

The maximum capacities of various grid connected SPV sub plants on the rooftops of different independent buildings in CVR College of Engineering are tabulated in Table I including the commercial dates of operation of each sub plant with their full name plate ratings.

TABLE I.

Details of Sub Plants, Their Capacities and Date of COMMENCEMENT OF PLANT

\begin{tabular}{|l|c|c|c|}
\hline \multicolumn{1}{|c|}{$\begin{array}{c}\text { Name of the Sub } \\
\text { Plant }\end{array}$} & $\begin{array}{c}\text { Location of the } \\
\text { Plant }\end{array}$ & $\begin{array}{c}\text { Installed } \\
\text { Power }\end{array}$ & $\begin{array}{c}\text { Date of } \\
\text { Commencem } \\
\text { ent of Plant }\end{array}$ \\
\hline CVR PG Block & EEE Block & $120 \mathrm{kWp}$ & $03-03-2014$ \\
\hline Single Axis Tracking & Main Block & $40 \mathrm{kWp}$ & $18-01-2015$ \\
\hline Library & Library Block & $20 \mathrm{kWp}$ & $23-10-2014$ \\
\hline $\begin{array}{l}\text { Single Axis Polar } \\
\text { Tracking }\end{array}$ & Main Block & $40 \mathrm{kWp}$ & $11-03-2015$ \\
\hline CVR CS Block & CSE Block & $60 \mathrm{kWp}$ & $22-10-2015$ \\
\hline CVR New & First Year Block & $80 \mathrm{kWp}$ & $03-03-2016$ \\
\hline $\begin{array}{c}\text { Overall Plant } \\
\text { Capacity }\end{array}$ & & $\mathbf{3 6 0 ~ k W p}$ & ---- \\
\hline
\end{tabular}

The important electrical apparatus that are required for the grid interactive SPV plants are: Solar PV Modules (Array), DC Solar Cables, Grid tied String Inverters, AC Cables, Junction Boxes, Switchgear Equipment, NetMetering facility (Bi-directional energy meter), Lighting Arrestors and electrical earthing's at appropriate locations. All the apparatus, components and devices used in this SPV sub-plants are according to the IEC 61724 standards as per the guidelines given by MNRE [7].

String inverter is the power electronic device that converts the DC electricity generated by the Solar Array from incident solar radiation into 3-phase AC electrical energy at PCC. Fig. 1 shows the $20 \mathrm{~kW}$ grid tied REFUsol 008K-020K string inverter used in this $20 \mathrm{~kW}$ grid connected solar PV plant. Its maximum efficiency is $98.2 \%$ at STC conditions. For every $20 \mathrm{~kW}$ array one independent string inverter is commissioned. Table II. shows the other important inverter data as given by the manufacturer.

The term solar PV array is defined as the interconnection of different solar modules either in series/ parallel depending upon system design, rating and configuration. The modules used in this rooftop SPV plant are supplied by Kohima Energy Pvt. Ltd. The model number of the module is $\mathrm{KE}-60-\mathrm{M} 250$, with peak DC electrical power rating of $250 \mathrm{Wp}$ at STC conditions $\left(25^{\circ} \mathrm{C}\right.$ ambient temperature, 1000 $\mathrm{W} / \mathrm{m}^{2}$ Insolation, Air mass ratio is 1.5). The other Specifications of Solar Module -KE-60-M250 are given in Table III. [8].

TABLE II

DETAILS OF GRID INTEGRATED REFUSOL 020K SOLAR STRING INVERTER

\begin{tabular}{|l|l|}
\hline & REFUsol 020K \\
\hline DC DATA & \\
\hline Recommended Max. PV Power, kWp & 21.6 \\
\hline MPPT Range & $480 \mathrm{~V}-850 \mathrm{~V}$ \\
\hline DC Start Voltage & $350 \mathrm{~V}$ \\
\hline Max. DC Voltage & $1000 \mathrm{~V}$ \\
\hline Max. DC Current & $41 \mathrm{~A}$ \\
\hline MPP Trackers & 1 \\
\hline AC DATA & \\
\hline Rated AC Power & $19.2 \mathrm{kVA}$ \\
\hline Max. AC Active Power & $19.2 \mathrm{~kW}$ \\
\hline Rated Power factor & 1 \\
\hline Max. AC current & $3 \times 29$ \\
\hline Distortion factor THD & $<1.8 \%$ \\
\hline Max. efficiency & $98.20 \%$ \\
\hline European efficiency & $97.80 \%$ \\
\hline
\end{tabular}

\section{REFUsol 008K-020K}

For medum-sized to megawatt installation

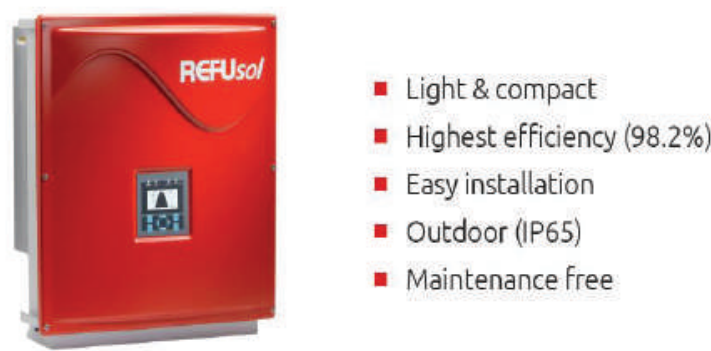

Figure 1. String Inverter used in SPV plant on rooftop of EEE Block

As per this design, there are 80 such KE-60-M250 solar modules. These 80 modules are further connected in 4 parallel strings. Each string consists of 20 modules in series. Fig. 2 shows the onsite photograph of a $20 \mathrm{~kW}$ rooftop grid connected plant commissioned on the Library block. Present investigation on performance ratio and degradation factor was performed on the $20 \mathrm{kWp}$ grid connected SPV plant commissioned on the rooftop of the library block. 


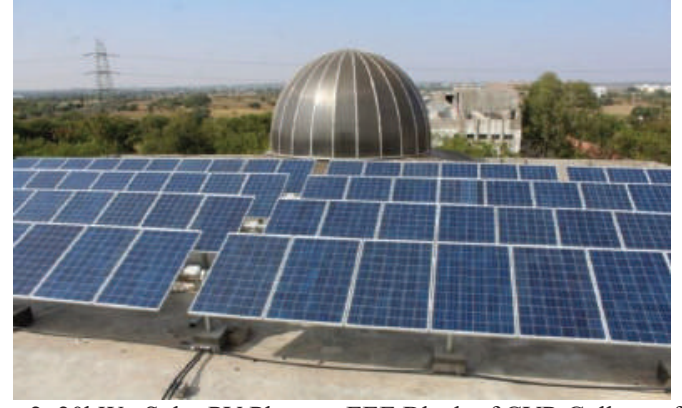

Figure 2. 20kWp Solar PV Plant on EEE Block of CVR College of Engineering

TABLE III.

SPeCifications of Solar MOdULE Kohima ENERGy PVT. LTd.

\begin{tabular}{|c|c|}
\hline STC-Irradiance of $1000 \mathrm{~W} / \mathrm{Sq} . \mathrm{m}$ at $25^{\circ} \mathrm{C}$ & KE-60-M250 \\
\hline Maximum Power $\left(\mathrm{P}_{\max }\right)$ & $250 \mathrm{~W}$ \\
\hline Maximum Power Voltage $\left(\mathrm{V}_{\mathrm{mp}}\right)$ & $31.44 \mathrm{~V}$ \\
\hline Maximum Power Current $\left(\mathrm{I}_{\mathrm{mp}}\right)$ & $7.95 \mathrm{~A}$ \\
\hline Open circuit Voltage $\left(\mathrm{V}_{\mathrm{oc}}\right)$ & $37.86 \mathrm{~V}$ \\
\hline Short Circuit Current $\left(\mathrm{I}_{\mathrm{sc}}\right)$ & $8.69 \mathrm{~A}$ \\
\hline Fill Factor & $75.98 \%$ \\
\hline Module Efficiency $(\mathrm{r})$ & $15.40 \%$ \\
\hline Nominal Operating Cell Temperature $(\mathrm{NOCT})$ & $45+2$ \\
\hline Temperature Coefficient of Isc $(\alpha)$ & $0.04 /{ }^{\circ} \mathrm{C}$ \\
\hline Temperature Coefficient of Voc $(\beta)$ & $-0.32 /{ }^{\circ} \mathrm{C}$ \\
\hline Temperature Coefficient of Pmax $(\Upsilon)$ & $-0.45 /{ }^{\circ} \mathrm{C}$ \\
\hline Cells per module & 60 \\
\hline Cell type & Multi - Crystalline \\
\hline Cell Dimensions & $156 \mathrm{~m} . \mathrm{m} \mathrm{X} 156 \mathrm{~m} . \mathrm{m}$ \\
\hline
\end{tabular}

\section{Performance Analysis (PR \& Degradation)}

\section{A. Performance Ratio (PR)}

Performance Ratio is one of the most significant metrics that is used for evaluating grid connected SPV plants. The empirical formula to evaluate the PR is as follows.

$\mathrm{PR}=$ Actual AC Energy generated by plant / Nominal Energy

Where Nominal Energy =

GHI (in $\mathrm{kWh} / \mathrm{m}^{2}$ ) X Rated module efficiency X Total Active $\mathrm{PV}$ area $\left(\right.$ in $\mathrm{m}^{2}$ )

The Performance Ratio is generally evaluated for a year to get a complete idea about the plant. PR also can be evaluated on daily, weekly, or monthly basis. Depending on the period of evaluation, corresponding parameters are chosen. In the above empirical formula, the denominator expression consists of GHI, Module efficiency and Active PV area. The value of the Module efficiency is picked from nameplate ratings given by the panel manufacturer. Active area is strictly the area covered by polycrystalline solar cells alone in the entire solar array. Whereas GHI of site or plant location depends upon several factors like ambient temperature, temperature of the cell, soil and losses due to dust, partial shading, weather conditions, etc. Hence calculation of PR takes all the above factors into consideration. Consequently, the influence of all the above parameters will be replicated in the Performance Ratio evaluation. If the evaluated PR value is near $100 \%$, one can conclude that PV plant is in excellent operating condition.

The manual procedure to evaluate the PR of the SPV plant is as follows:

- Determine the time of analysis (Optimum period is one calendar year).

- $\quad$ Active PV area of the solar array has to be computed by number of modules used in PV array.

- Collect the information about PV module efficiency from the datasheets.

- AC electrical energy output of the Plant from the inverter data.

- By using the irradiance sensor (Pyranometer) gather the values of the measured solar insolation values.

$\mathrm{PR}$ is the appropriate performance metric to compare the performance of various SPV plants at different locations independent of weather and climate conditions. Deviations from the expected PR indicate either a fault in the system or a problem within the PV plant itself.

PR is the most accepted global standard to measure the performance of a SPV plant. Periodically few stakeholders and Independent Power Producers (IPP) are very keen to evaluate and compare the PR's of the dissimilar rated solar plants across the globe, which are located at different geographical locations [9-16].

\section{B. Degradation Factor}

Degradation is an industry term that is used to describe the decrease in the power output of the solar PV plant over a period of time. The degradation mainly happens in solar modules, inverters and Cables used in the PV plant. All components definitely degrade, but degradation rate is not uniform for all the equipment used in the system. High attention must be paid towards module degradation. Because, solar modules are the critical devices that collect the solar energy from the sun and convert it into DC electricity. If the panels/modules degrade at faster rate, the output power from the modules will decrease day by day resulting in poor energy yield of the plant for life time. Factors affecting the degree of degradation include, quality of the material used in manufacturing, packing of solar cells, and solar cell technology. Other important factor is breakage of Ethylene Vinyl Acetate (EVA) encapsulation, which is used as a back sheet of the PV module by UV light.

\section{RESUlTS \& DISCUSSIONS}

Solar Radiation values of the site are gathered from the data available by the NASA at the nearest location. The table IV demonstrates the monthly solar radiation values at the site for the year 2015 and 2016. Fig.3 shows the graphical representation of the same for the years 2015 and 2016 of the 20kWp SPV plant on rooftop of Library Block. 
TABLE IV.

MONTH Wise SOlar Radiation VALUES For the YeARS 2016 AND 2015 OF 20KW SPV PLANT

\begin{tabular}{|c|c|c|}
\hline Month \& Year & $\begin{array}{c}\text { Solar } \\
\text { Radiation } \\
\mathbf{2 0 1 6}\end{array}$ & $\begin{array}{c}\text { Solar } \\
\text { Radiation } \\
\mathbf{2 0 1 5}\end{array}$ \\
\hline January & 158.4 & 154.7 \\
\hline February & 169.6 & 169.9 \\
\hline March & 178.9 & 184.9 \\
\hline April & 188.3 & 197.8 \\
\hline May & 201.1 & 201.7 \\
\hline June & 153.2 & 151.4 \\
\hline July & 140.4 & 169.3 \\
\hline August & 150.4 & 152.4 \\
\hline September & 111.6 & 149.5 \\
\hline October & 148.6 & 155.5 \\
\hline November & 139.7 & 153.2 \\
\hline December & 143.2 & 149.7 \\
\hline Average & 156.95 & 165.83 \\
\hline
\end{tabular}

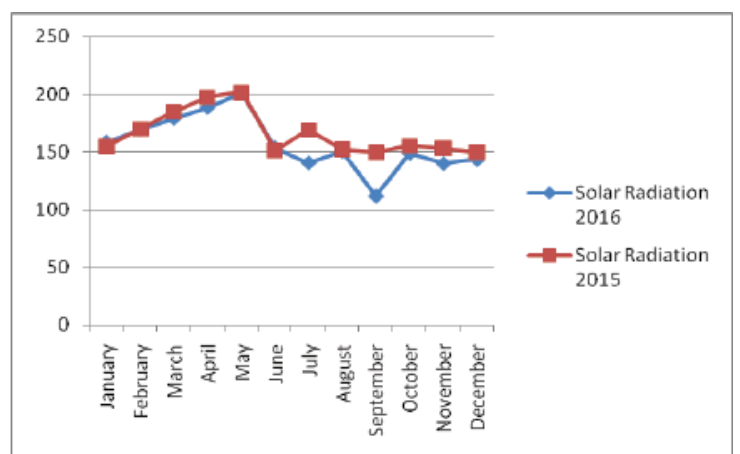

Figure 3. Monthly Solar radiation values for the years $2015 \& 2016$ of $20 \mathrm{~kW}_{\mathrm{p}}$ SPV plant on rooftop of Library Block

A. Calculation of Performance Ratios ( at STC)

Table V and Table VI show the calculated monthly nominal Performance Ratios of the plant at STC conditions for the year 2015 \& 2016 respectively. All the PR values are calculated by looking at the name plate details of STC conditions (STC conditions are $25^{\circ} \mathrm{C}$ of ambient temperature, Solar radiation of $1000 \mathrm{~W} / \mathrm{m}^{2}$ and Air-mass ratio of 1.5). The calculated Performance Ratio's at STC conditions are also called as Nominal Performance Ratios. Temperature corrected Performance ratio is getting popular nowadays for better analysis. However, Nominal Performance ratios are used in this work for the analysis of plant performance.

These monthly calculated PR's are compared and analyzed to estimate the degradation of the plant output. The important fact to be understood here is, plant output is always dependent upon solar radiation input to the modules. If the radiation is high, energy output will be high and vice versa. Estimating the degradation rate only using energy output will not give feasible results. For instance, from the Fig. 3, during the months of July and September, solar radiation values are less in the year 2016 compared to 2015 . However, corresponding PR's are higher in the year 2015 than in 2016. Hence, it is always better to compare the
Performance Ratio's of the plant than comparing the energy output.

TABLE V.

Month-Wise Average Actual ac Energy Generated, Average THEORETICAL DC ENERGY COULD GENERATED AT $25^{\circ} \mathrm{C}$ AND NOMINAL PR OF 20KW SPV PLANT FOR THE YEAR 2015

\begin{tabular}{|c|r|r|r|}
\hline & $\begin{array}{c}\text { AC } \\
\text { Energy } \\
\text { Month \& Year }\end{array}$ & $\begin{array}{c}\text { Theoretical } \\
\text { PC Energy } \\
\text { Year 2015 }\end{array}$ & PR2015 \\
\hline January & 2611.85 & 2782.92 & 93.85 \\
\hline February & 2787.53 & 3056.36 & 91.20 \\
\hline March & 2988.03 & 3326.20 & 89.83 \\
\hline April & 2929.68 & 3558.26 & 82.33 \\
\hline May & 2973.22 & 3628.42 & 81.94 \\
\hline June & 2262.63 & 2723.56 & 83.08 \\
\hline July & 2567.97 & 3045.57 & 84.32 \\
\hline August & 2365.32 & 2741.55 & 86.28 \\
\hline September & 2351.52 & 2689.38 & 87.44 \\
\hline October & 2588.20 & 2797.32 & 92.52 \\
\hline November & 2581.72 & 2755.94 & 93.68 \\
\hline December & 2518.12 & 2692.98 & 93.51 \\
\hline Average & 2627.15 & 2983.20 & 88.06 \\
\hline
\end{tabular}

TABLE VI.

Month-Wise Average Actual ac Energy Generated, Average THEORETICAL DC ENERGY COULD GENERATED AT $25^{\circ} \mathrm{C}$ AND NOMINAL PR OF 20KW SPV PLANT FOR THE YEAR 2016

\begin{tabular}{|c|c|c|c|}
\hline Month \& Year & $\begin{array}{c}\text { AC } \\
\text { Energy } \\
\text { Produced } \\
\text { Year } \\
\mathbf{2 0 1 6}\end{array}$ & $\begin{array}{c}\text { Theoretical } \\
\text { DC Energy } \\
\mathbf{2 0 1 6}\end{array}$ & PR2016 \\
\hline January & 2606.70 & 2849.48 & 91.48 \\
\hline February & 2744.10 & 3050.96 & 89.94 \\
\hline March & 2791.40 & 3218.26 & 86.74 \\
\hline April & 2720.00 & 3387.36 & 80.30 \\
\hline May & 2788.50 & 3617.62 & 77.08 \\
\hline June & 2207.40 & 2755.94 & 80.10 \\
\hline July & 2063.50 & 2525.68 & 81.70 \\
\hline August & 2283.10 & 2705.57 & 84.39 \\
\hline September & 1720.40 & 2007.59 & 85.69 \\
\hline October & 2429.60 & 2673.19 & 90.89 \\
\hline November & 2314.10 & 2513.09 & 92.08 \\
\hline December & 2355.90 & 2576.05 & 91.45 \\
\hline Average & 2418.72 & 2823.40 & 85.67 \\
\hline
\end{tabular}




\section{B. Calculation of Degradation Factor}

Table VII compares the amount of AC energy generated by the plant in the year $2015 \& 2016$. Fig. 4 shows the graphical comparison of the same. Similarly, Table VIII shows the comparison of the Performance Ratio's of the plant for the year 2015 \& 2016. Fig.5 represents the graphical comparison of the same data. From the graphs, it is observed that, the Performance Ratio's of the plant for the year 2015 is slightly higher than the performance Ratio's for the year 2016. This drop in the performance ratio is due to degradation in various components used in the system. If the degradation factor is even $1 \%$ per a year, it may result in high payback period. Fig. 6 shows the graphical representation of the month-wise percentage degradation values [17].

TABL VII.

Month Wise AC ENERgy Produced For the YeArs 2016 AND 2015 AF 20KW SPV PLANT

\begin{tabular}{|c|c|c|}
\hline $\begin{array}{c}\text { Month \& } \\
\text { Year }\end{array}$ & $\begin{array}{c}\text { AC Energy } \\
\text { Produced in } \\
\text { Year 2016 }\end{array}$ & $\begin{array}{c}\text { AC Energy } \\
\text { Produced in Year } \\
\mathbf{2 0 1 5}\end{array}$ \\
\hline January & 2606.70 & 2611.85 \\
\hline February & 2744.10 & 2787.53 \\
\hline March & 2791.40 & 2988.03 \\
\hline April & 2720.00 & 2929.68 \\
\hline May & 2788.50 & 2973.22 \\
\hline June & 2207.40 & 2262.63 \\
\hline July & 2063.50 & 2567.97 \\
\hline August & 2283.10 & 2365.32 \\
\hline September & 1720.40 & 2351.52 \\
\hline October & 2429.60 & 2588.20 \\
\hline November & 2314.10 & 2581.72 \\
\hline December & 2355.90 & 2518.12 \\
\hline Average & 2418.72 & 2627.15 \\
\hline
\end{tabular}

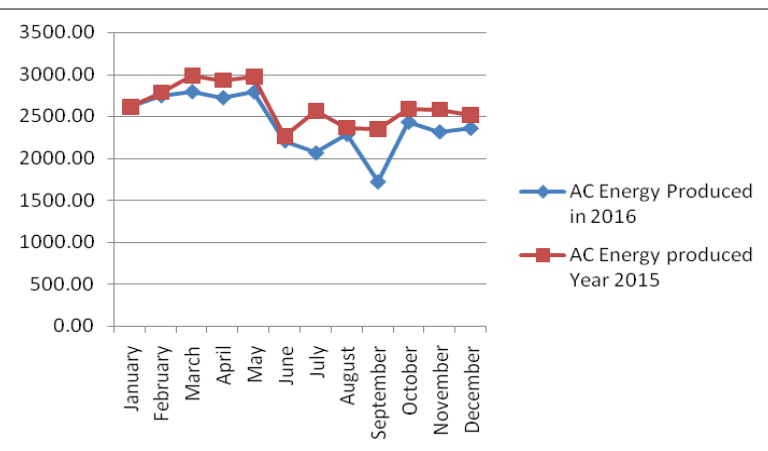

Figure 4. Monthly $\mathrm{AC}$ energies produced by the plant for the years $2015 \& 2016$ of $20 \mathrm{~kW}_{\mathrm{p}}$ SPV plant on rooftop of Library Block
TABLE VIII.

Month Wise Performance Ratio Values for the Years 2016 AND 2015 OF 20KW SPV PLANT

\begin{tabular}{|c|c|r|c|}
\hline Month \& Year & PR 2016 & PR 2015 & $\begin{array}{c}\text { \% } \\
\text { Degradation }\end{array}$ \\
\hline January & 91.48 & 93.85 & 2.53 \\
\hline February & 89.94 & 91.20 & 1.38 \\
\hline March & 86.74 & 89.83 & 3.45 \\
\hline April & 80.30 & 82.33 & 2.47 \\
\hline May & 77.08 & 81.94 & 5.93 \\
\hline June & 80.10 & 83.08 & 3.59 \\
\hline July & 81.70 & 84.32 & 3.10 \\
\hline August & 84.39 & 86.28 & 2.19 \\
\hline September & 85.69 & 87.44 & 1.99 \\
\hline October & 90.89 & 92.52 & 1.77 \\
\hline November & 92.08 & 93.68 & 1.70 \\
\hline December & 91.45 & 93.51 & 2.20 \\
\hline Average & 85.67 & 88.06 & 2.72 \\
\hline
\end{tabular}

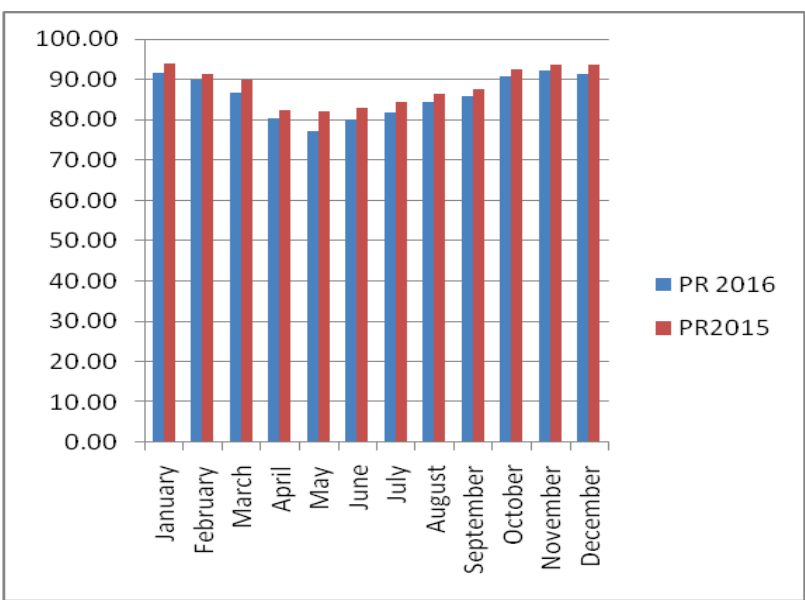

Figure 5. Monthly Performance Ratios of the plant for the years $2015 \& 2016$ of $20 \mathrm{~kW}_{\mathrm{p}}$ SPV plant on rooftop of Library Block

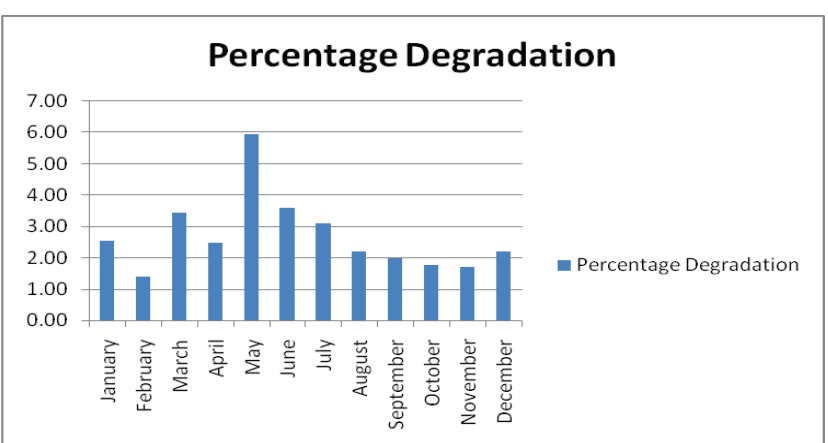

Figure 6. Monthly percentage degradation of $20 \mathrm{~kW}_{\mathrm{p}}$ SPV plant on rooftop of Library Block from 2015 and 2016 PR data

\section{CONCLuSions}

In this research, the effect of degradation on the Performance of $20 \mathrm{kWp}$ grid connected SPV plant on rooftop of Library block was analysed from 2015\&2016. During the period March to June, the degradation values are significantly more because of increase in ambient temperature causing more power losses at module level. The 
calculated degradation factors were found to be a little higher than expected values. These values should be minimised by taking proper measures for better performance of the solar plant in terms of degradation. It is recommended that modules must be cleaned at regular intervals either before sunrise or after sunset as the main reason for degradation is observed to be dust and soling. The maximum value of the performance ratio is observed in the month of Jan 2015 with $93.85 \%$ and minimum value is observed to be in the month of May 2016 with $77.08 \%$. After comparing the PR's of plant for successive years, the maximum degradation is observed to be in the month of May'16 because of high ambient temperature and minimum in the month of February'16 because of clear sky conditions. It is also observed that the overall plant performance is satisfactory as per industry standards.

\section{REFERENCES}

[1] Razykov TM, Ferekides CS, Morel D, Stefanakos E, Ullal HS, Upadhyaya HM. Solar photovoltaic electricity: current status and future prospects. Sol Energy 2011; 85: 1580;1608.

[2] Ali Hajiah, T.K., K. Sopian, M. Sebzali1, Performance of grid connected photovoltaic system in two sites in Kuwait, 2013, Kuwait Institute for Scientific Research (KISR): Kuwait. International Journal of Photoenergy Volume 2012 (2012), Article ID 178175 , p. 20.

[3] S. Elhodeiby, H. M. B. Metwally, and M. A. Farahat, "Performance Analysis of $3.6 \mathrm{~kW}$ Rooftop Grid Connected Photovoltaic System in Egypt," in Proceedings of International Conference on Energy Systems and Technologies (ICEST 2011), Cairo, Egypt, 2011, pp. 151157.

[4] S. Singh, R. Kumar and V. Vijay, "Performance analysis of 58 $\mathrm{kW}$ grid-connected roof-top solar PV system," Power India International Conference (PIICON), 2014 6th IEEE, Delhi, 2014, pp. 1-6.

[5] Yan S, Lai-Cheong C, Lianjie S, Kwok-Leung T. Real-time prediction models for output power and efficiency of gridconnected solar photovoltaic systems. Appl Energ 2012; 93: 319;326.

[6] Al-Sabounchi AM, Yalyali SA, Al-Thani HA. Design and performance evaluation of a photovoltaic grid-connected system in hot weather conditions. Renew Energy 2013; 53: $71 ; 78$.

[7] Data sheet of REFUlog Inverters

[8] Data sheet of Kohima Energy Pvt Ltd.

[9] Whitepaper on PR vs. CUF provided by CHROSIS Sustainable Solutions.

[10] Padmavathi K, Daniel SA. Performance analysis of a $3 \mathrm{MWp}$ grid connected solar photovoltaic power plant in India. Energy Sustainable Dev 2013;17:615-25.

[11] B.S.Kumar, K.Sudhakar, Performance of evaluation of 10MW grid connected Photovoltaic power plant in India, Energy Reports 1(2015) 184-192.

[12] Shukla, A.K., Sudhakar, K., Baredar, P., 2016a. Simulation and performance analysis of $110 \mathrm{kWp}$ grid-connected photovoltaic system for residential building in India: A comparative analysis of various PV technology. Energy Rep. $2,82-88$.

[13] Shukla, A.K., Sudhakar, K., Baredar, P., 2016b. Design, simulation and economic analysis of standalone roof top solar PV system in India. Sol. Energy 136, 437-449

[14] Kamal Attari, Ali El Yaakoubi,Adel Asselman Comparative Performance Investigation between Photo-voltaic Systems from two different cities, 10th International conference interdisciplinary in Engineering, Proceedia Engineering
181(2017) 810-817. Elsevier, available on www.sciencedirect.com

[15] P.Rajesh Kumar, D.Koteswara Raju, Rajib Kumar Kar "Performance Metrics of Grid Connected Solar PV Plant on Roof top of CVR College of Engineering- A Case Study" Journal of Green Engineering Vol. 7, 99-128 -July 2017.

[16] "Effect of Ambient temperature on performance of GridConnected inverter installed in thailand", komonpan, international journal of photo-energy,volume 2014, hindawi publishing.

[17] Role of performance metrics to identify the Gaps in solar power generation, P.Rajesh Kumar $4^{\text {th }}$ international conference on electrical energy systems ICEES 2018 Feb 2018 